$$
\begin{aligned}
& \text { "العلاقة بين الدوجماطيقية وأحادية العقلية" } \\
& \text { زينب رمضان جابر فرغلى - مانى } \\
& \text { باحثة ماجستير - كلية الآداب جامعة المنيا }
\end{aligned}
$$

\title{
مقدمة:-
}

يحاول البحث فحص مفهوم نفسى تراه الباحثه أنه مهم جداً وخاصة في عصرنا هذا ألا وهو أحادية العقلية single mindedness وذلك فن إرتباطه بالدوجماطيقية . فأحادية العقل هو نمط / سمة سلوكية غير سوى تحتوى على عدد كبير من الأبعاد مثل

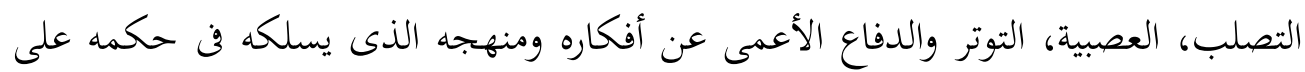

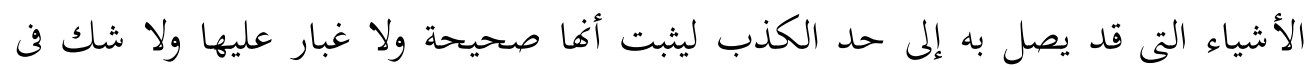
صحتها فقد يدنس الحقائق بما تتوافق مع أرائه وأفكاره مما يؤدى به طبيعياً إلى الشعور بالتوتر إنى

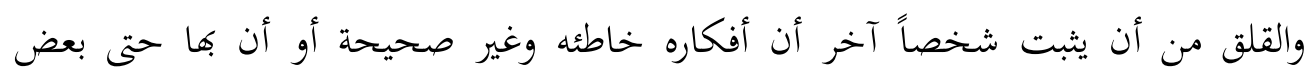
الشك في مصدقيتها المطلقة، مما يؤدى إلى نشوب الخلافات بين الشخص أحادى العقلية وبين الآخرين الذين يختلفون معه آرائه ومعتقداته وغيرها من الأشياء التى يسلم بأها في كمال من الصحة. فالشخصية أحاديه العقلية شخصية جامدة لا تسلم بتعدد الرؤى ولا يجيد للمشكلة إلا حل واحد فقط لا ثان له ولا يسلم بحق الإختلاف الفكرى وهو شخص لا لا بله يسمح لذاته بالتغير والتطور بما يتماشى مع الحياة المعاصرة المتطورة والمتغيرة بإستمرار.

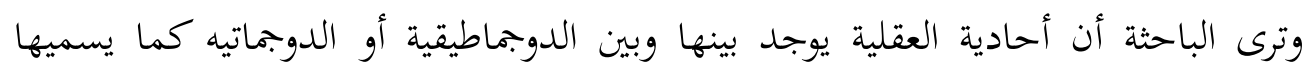
البعض يوجد تشابه أو يمكن القول أن الدوجماطيقية تدخل في بعض جوانب مفهوم أحادية العقلية. فالدوجماطيقية تتمثل فن فرض الرأى بالسلطة وإمتلاك الحقيقة المطلقه بشكل شامل دون

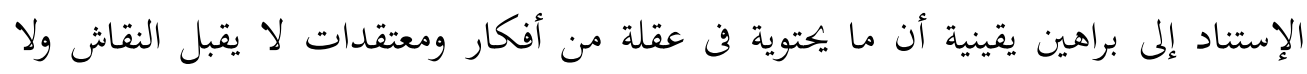
التغيير حتى وإن الظروف تغيرت، ولا يهاول أن يخضع أفكاره ومعتقداته إلى تحليل منطقى حتى يتأكد من صحتها. 
فالشخص الدوجماطيقى لا يمارس شخصيته أو لا يستطيع أن يمارس ما بداخله من أفكار ومعتقدات إلا على آخر ضعيف يسمح لغيره أن يتحكم فيه لاغياً شخصيته وكيانه.

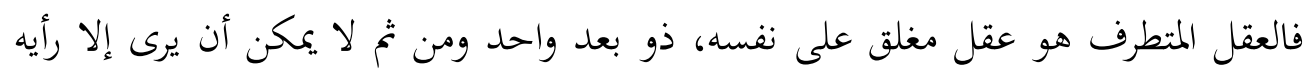
وأفكاره ومعتقداته ويراها أها مؤكده لا سبيل فيها للنقاش.

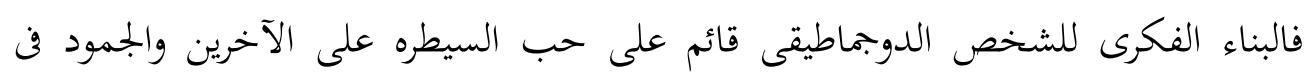
التفاعل فهو شخص منغلق فكرياً.

$$
\text { تبرز أهمية الدراسة من خلال النقاط التالية :- }
$$

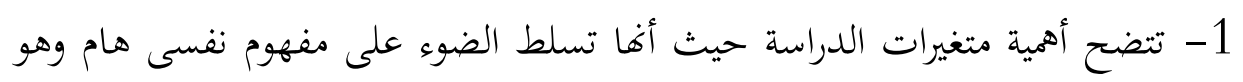

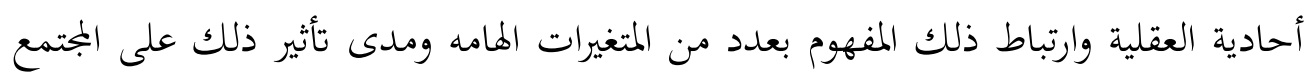
والعلاقات البين شخصية وتقبل الأمر بكل أختلافاته .

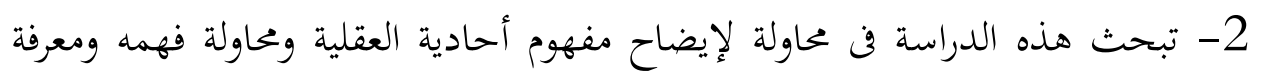

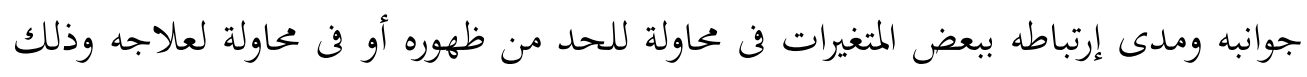

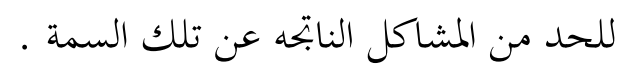

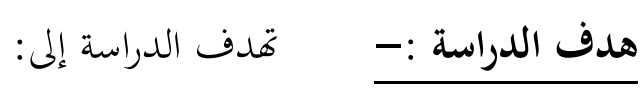
ه إستكشاف جوانب آخرى للمتغير أحادية العقلية . معرفة الفروق في بعض جوانب شخصية طلاب الجامعة / الثانوى . محاولة معرفة مدى إرتباط الدوجماطيقية بمتغير أحادية العقلية .

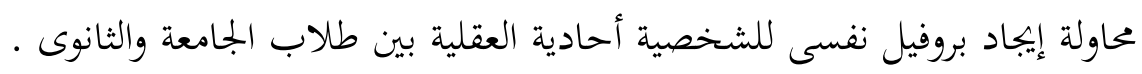

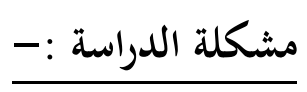

هل توجد علاقة بين أحادية العقلية وكل من القلق والكمالية والدوجماطيقية ؟

$$
\text { مفاهيم الدراسة :- }
$$


إن مفهوم أحادية العقلية مفهوم قديم قدم الإنسان على الأرض ويضم بداخله مفاهيم كثيرة

فهوليس مفهوم أحادى البعد بل متعدد الأبعاد ( أو الأقطاب) .

رغم تطابق الناس فن تكوينهم الفسيولوجى إلا أغم يتفاوتون فكرياً وروحياً ويتعددون

عرقياً وجعرافياً فالإنسان أحادى التكوين ولكنه متعدد التكوين العقلى والفكرى إن الإنسان

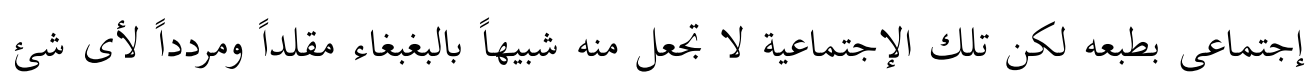
دون وعى وتفكير بل الإنسان بوعيه وعلمه وإرادته يمكنه الخروج من حالة الغوغائيه إلى حالة السيادة التى تمكن الإنسان من إمتلاك عقله وإرادته .

فالعقل الأحادى بلغ ذروته الإقصائية في قمع ومنع وكبت كل فكره مغايرة ومناقدة ومضادة له قد تنزع عنه حالة القداسة التى يشعر بها حول أفكاره ومعتقداته وتخضعه للمسائله أو النقد أو تؤدى إلى قبول التعددية التى من شأغها تغيير المعايير السائدة .لذا سعى الفكر الواحد إلى قبول جميع العقول والأفكار فن إطار فكرى أحادى وهذا نسق مرت به أغلب

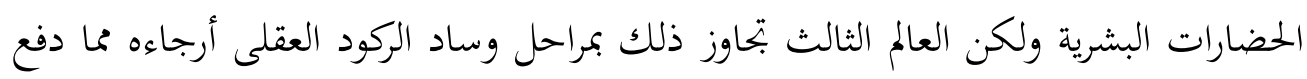
بعض المفكرين إلى توجيه التهمه إلى العقل العربى وقامت دراسات وأبحاث عديدة ومشاريع فكرية حول نقد العقل العربى والإسلامى وإقامهما بأغما السبب وراء الركود الفكرى وأحادية

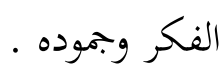

يشير التحليل النظرى إلى أن أحادية العقلية إنما هى إختزال لعدد من أنماط السلوك غير السوية مثل التعصب والتصلب والنفور من الغموض والدوجاطيقية بالإضافه إلى الإنغلاق

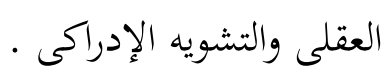

صاحب الشخصية أحادية العقل هو شخص يتسم سلوكه بالإنتظام في مسارات محدده صارمه ضيقة تشبه سلوك الفأر الذى تعلم المتاهه وحيث ينطلق من بدايتها إلى فايتها بسرعة ودقة دون أن يبحث عن مسارات جديدة أو يتوقف عند تنوع الإختيارات ويتناقض هذا 
النمط مع ثراء الحياة الإنسانية بما يتضمنه من تنوع وعمق وتفاعل وخصوبة . ( صفوت فرج، 2001 ، ص 10 ) فهو إنسان يسلك طريق تفكيرذو إبتحاه واحد وذلك معتمداً على ما

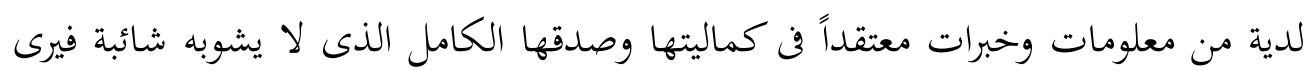

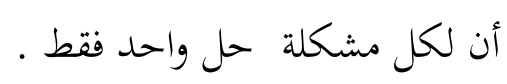

بالنسبة لهذا الإنسان الذى يعيش حضارة يشارك في ثرائها أخذاً وعطاءً يصبح سلوك الفأر" الأحادى" إختزالاً للحياة والسلوك في صيغة ميكانيكية تتسم بالفقر والجمود ، تحل السلوك إلى مسارات صارمة وصيغ ثابتة وتحول التفكير إلى نمط التداول الإلكترونى للمعلومات أى الذكاء الإصطناعى " "artifical intelligence الذى تسقط فيه إعتبارات السياق وإعتبارات الوجدان ودفئه وثرائه . - هذا التكوين للعقل له أثار إجتماعية مدمره ، فمثلاً اذا إختلف السياسيون تراشقوا بتهم العدالة والخيانة واذا إحتدمت وتأزمت المناقشة بين أرائهم يمكن أن يصلوا إلى حد تكفير

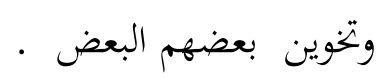
من الممكن أن تظهر هذه الأحادية العقلية وتزداد في بعض الأوقات ولكنها موجودة دائماً ويجب ان يكون المسلم بعيد كل البعد عنها لأفا تدل على قصر نظر وأنانيه وغرور وهذا ما فهى عنه الله تعالى في القرآن الكريم . single mindedness مفهوم أحادية العقلية:-

أصبح المجتمع الإنسانى اكثر من اى وقت مضى مجتمعاً منفتحاً على الثقافات ، ومعترفاً

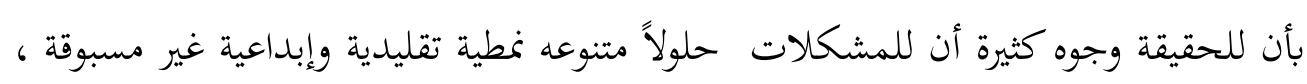
تختلف فيمابينها ولكنها فعالة وايبابية بدرجات متفاوته ومتباينه . إن التعايش مع الإفكار المعارضة والتسليم بحق الإختلاف الفكرى والسلوكى هى من سمات الشخص السوى الذى يسعى إلى إكتشاف المجهول ويرغب فن التواصل مع الآخرين والإنفتاح 
على العالم والمجتمع والإستفاده من الخبرات الجديدة وبتربة الأفكار وإختبار صحتها وتطوير شخصيته وتفكيره وبالتالى تطور سلوكه وفكره .

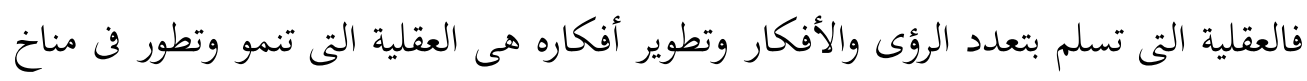
صحى وسليم وتسهم ف ترسيخ القيم وحقوق الإختلاف والتقدم والتطور والحوار مع الآخر المعارض فهى شخصية بناءه مصلحه ومتطوره وليست مدمره وهدامه . .

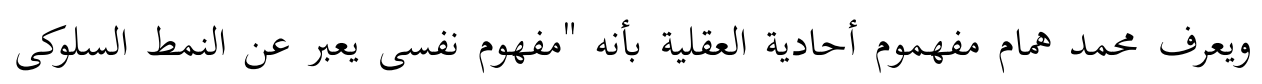

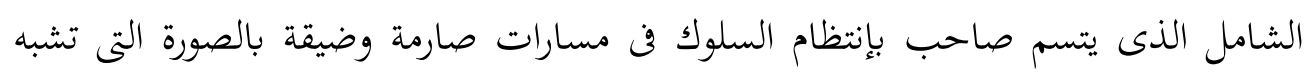

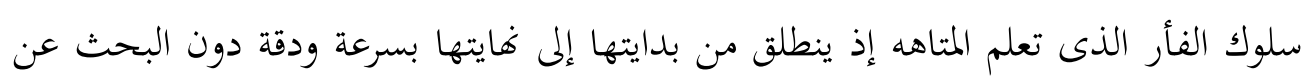

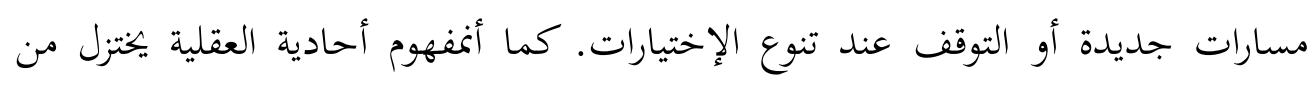

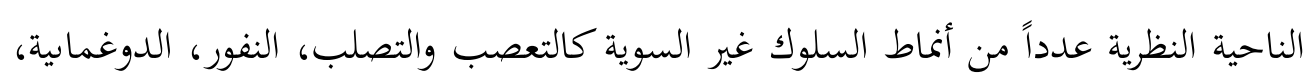
والإنغلاق العقلى، والتشوه الإدراكى. يقول صفوت فرج يتحدد السواء دائماً من خلال عدم السواء كما تتكشف طبيعة الإدرأ

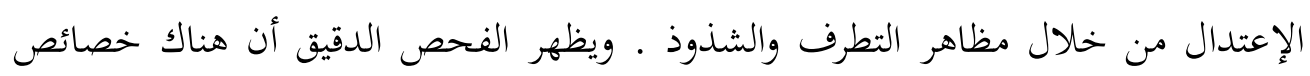

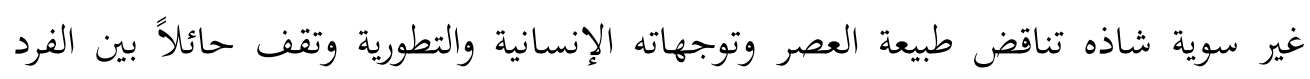
ومواكبة حركة التطور الإجتماعى والتقدم الحضارى.

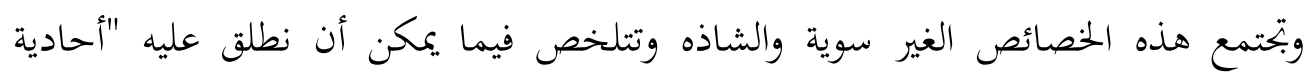

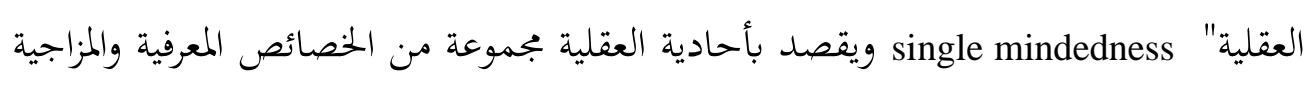

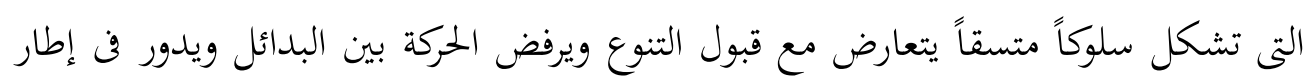

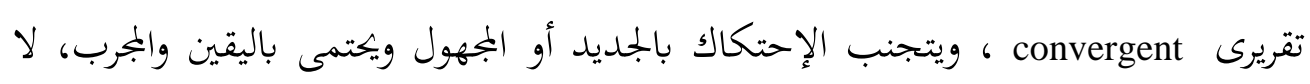

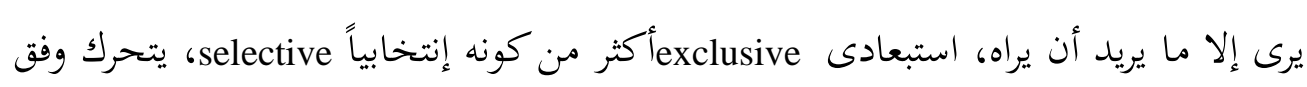

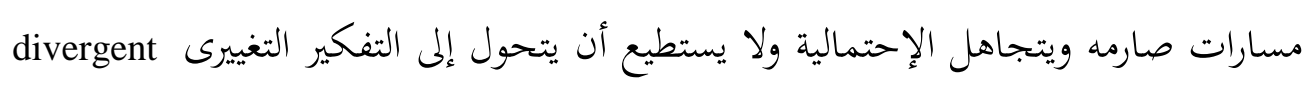


(صفوت) الطابع ، ويعزل نفسه عن مجتمعه ويكرس نفسه لأهداف ضيقه ومحدده . فرج ،

يعد من الصعب فصل مفهوم أحادية العقلية عن بعض المفاهيم مثل التصلب (الجمود العقلى) Rigidity ، التحيز Bias ، التعصب prejudice ، النفور من الغموض ، القلق single ألذى يشبه كثيرا أحادية العقلية one Demension view وأيضاً أحادة الرؤية Anxiety فت فتتداخل كل هذه المفاهيم مع مفهوم أحادية العقليه التى يمكن إعتبارها مفهوم عام يضم ويختزل مفاهيم كثيرة بداخله . وتتكلم ملاك الخالدى عن " أحادية العقلية " أن العقل الأحادى بلغ ذروة إقصائية في قمع كل فكره مغايرة قد تنزع عنه حالة القداسة وتخضعه للمساءلة أو النقد أو تؤدى إلى القبول بالتعددية التى تفضى إلى النسبية التى من شأها تغيير المعايير السائدة لذى سعى الفكر الواحد لقولبة جميع العقول في إطار فكري أحادي، وهذا بالتأكيد ليس حصراً على العالم الثالث إنما نسق مرت به أغلب الحضارات البشرية إلا أها بتحاوزته بمراحل . (ملاك الخالدى ، 2012) (ملاكس)

\section{Dogmatism - - - - 2}

يعد الجمود والانفتاح الفكري قديماً قدم الإنسان ويعد الانغلاق المعرفي من أخطر المشكلات

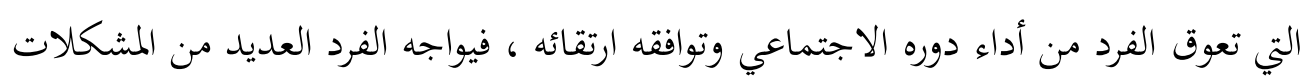

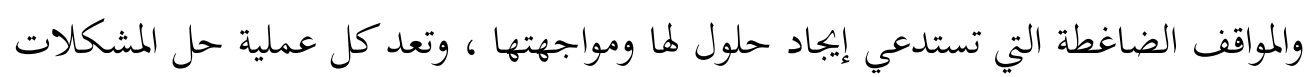

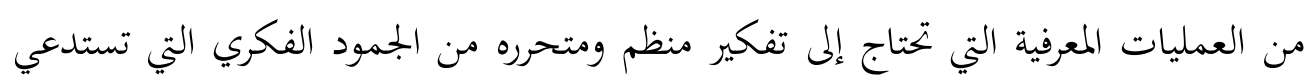

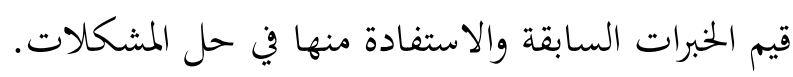
الدوجماطبقية لها ترجمات عديدة مثل قطعية وجزمية وتوكيدية ويقينية والجمود الفكري والانغلاق الفكري وغيرها من المسميات والترجمات وهى كلها تعني الاعتقاد الجازم واليقين المطلق دون الاستناد إلى براهين يقينية وإنكار الأمر ورفضه باعتباره على باطل مطلق طالما 
يخالف الرأي الخاص بالدوجماتي ومن ثم فهي مبدأ التعصب وسمة لكل متزمت ومنشأ الحروب

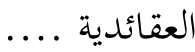
والدوجماطيقية ليست مذهباً فلسفياً أو دينياً .والدوجماطيقية في أكثر معانيها انتشاراً هي سمة وطريقة تفكير تتسم بها أي فرقة أو مذهب او فئة أو فلسفة تزعم امتلاك الحقيقة المطلقة

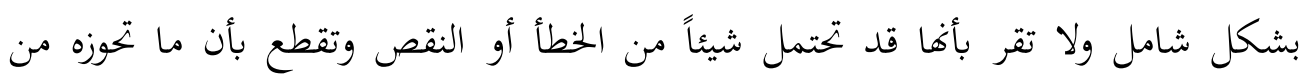

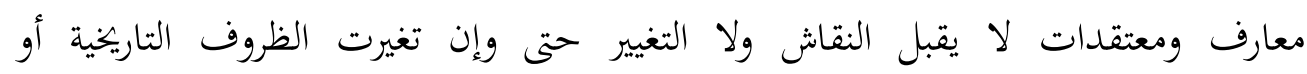

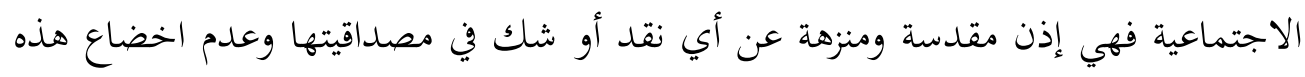

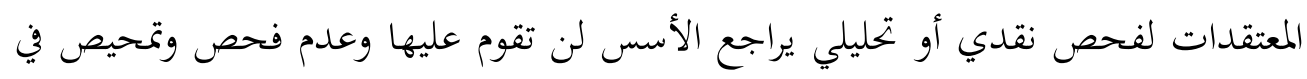
الطرق التي توصل المعرفة والتي على أساسها يبني الدوجماتي رؤيته وأفكاره ومعتقداته.

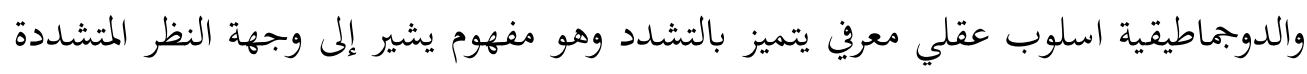

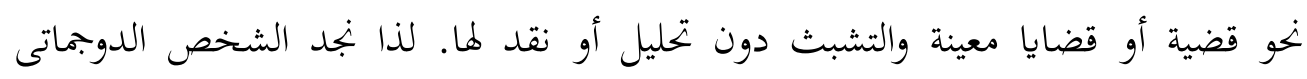
يتمسك بأفكاره ولا يسمح بالنقاش حولها. والسلوك الإنساني من السمات الهامة التي تحدد معالم شخصية الفرد وتبين قدراته وإمكانياته

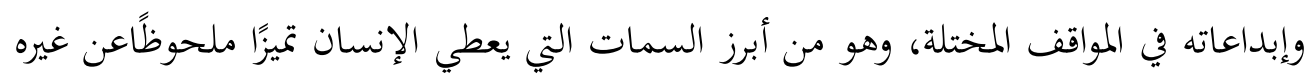

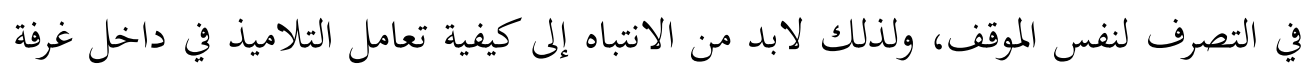

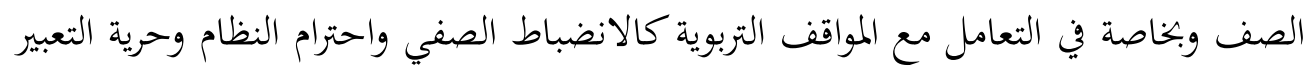

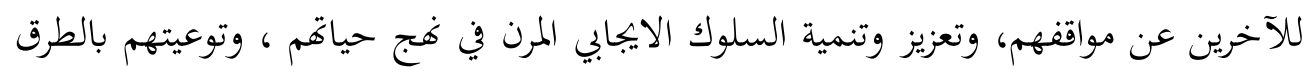

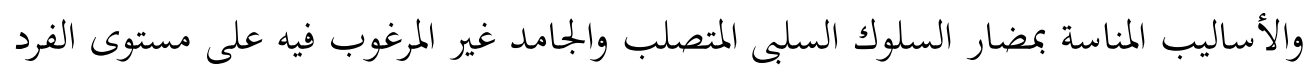
والأسرة والمدرسة والمجتمع.

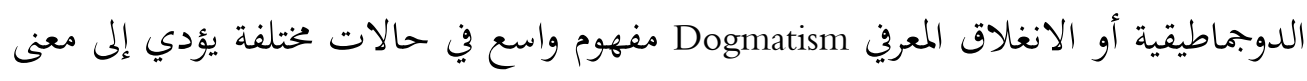

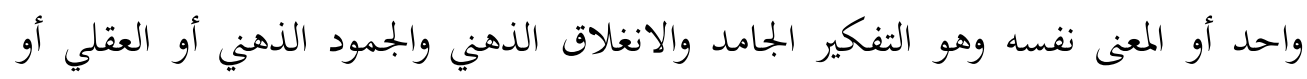

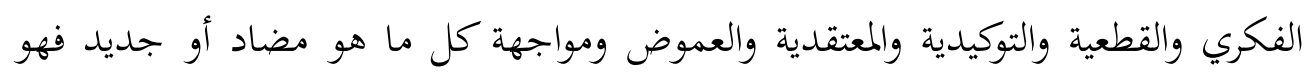
يقع بين قطبي الصواب والخطأ أو أبيض وأسود. 
أن الشخص الجامد ذهنياً (أي منغلق الذهن) يتميز بدرجة مرتفعة من الاستعداد لرفض

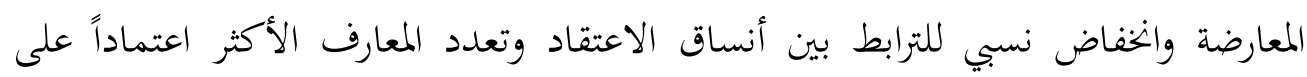
رغبات غير ملائمة أو على سلطة خارجية.

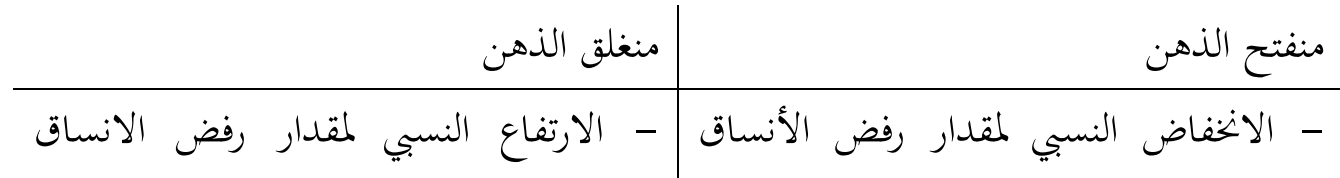

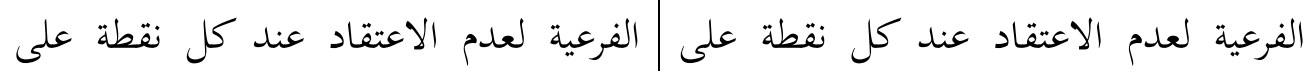
المتصل. المتصل. - يوجد اتصال بين العناصر الجزئية داخل - توجد عزله بين العناصر الجزئية داخل وبين

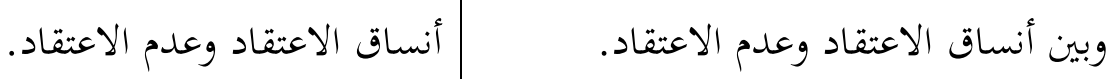

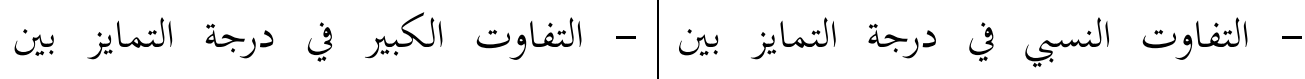

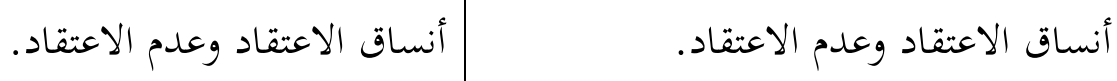

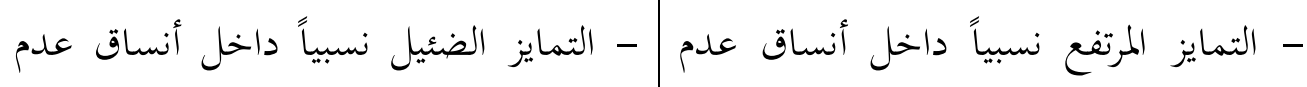

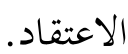

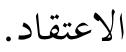

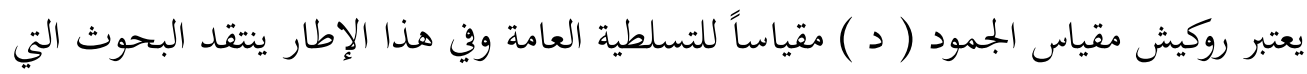
أجريت في نطاق الشخصية التسلطية باستخدام مقياس الفاشية ( ف ) وذلك لأن الباحثين

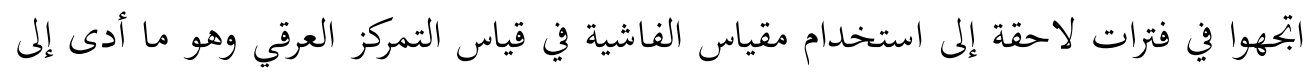
الخلط في المفاهيم. هنا رأى روكيش أن مفهوم الجمود يماثل مفهوم (( التسلطية العامة )) التي ترادف مفهوم

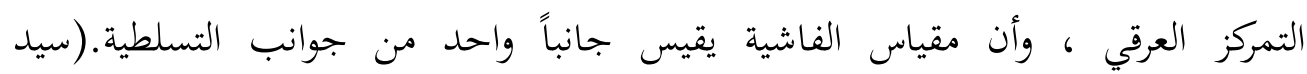
غريب، (1989، ص ص 73:54) ويوضح (( جمال صليبا )) 1971 هذا التطور بقوله (( الدوجماتية منذ أيام كانت دلاله لا لا

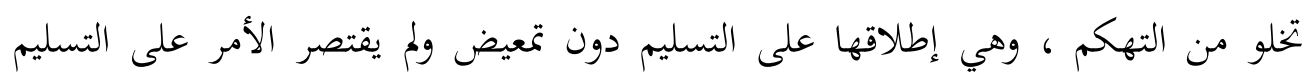

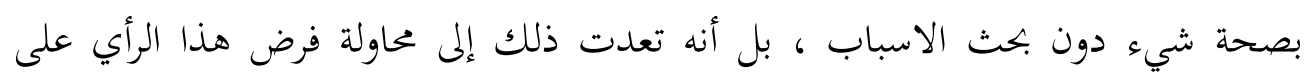

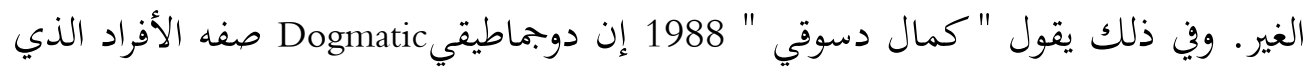


يسعون لفرض آرائهم بالسلطة أو النفوذ أو التعليم الذي يطالب التلاميذ بقبول الأفكار من

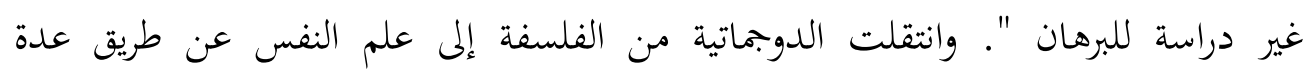

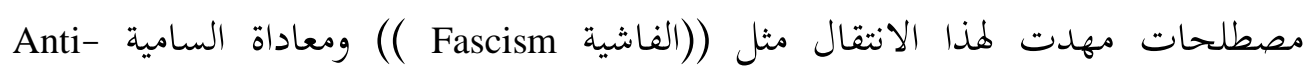
.Nazism والنازية semitism ويذكر (ناصر دسوقي) 1991 أن (فروم) يرى أن النظام الفاشي يعد نظاماً تسلطياً نظراً لما تتيحه للسلطة من هيمنه وسيطرة على المجتمع والبناء السياسي. ومن ثم فقد اهتم بعض

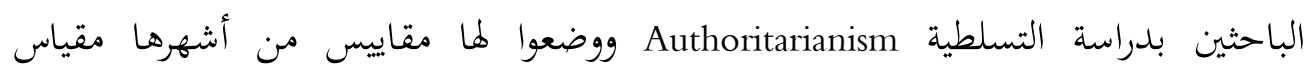
أدورنو Adorno الذي يقيس المعتقدات الفاشية وسمى مقياس الفاشية Fascism. ويذكر (روكيش) 1960 أن (أدورنو) وزملاؤه قد اعتبروا أن مقياس الفاشية لا يقيس معليس التسلطية الفاشية فقط وإنما يقيس الشخصية التسلطية ككل. وأشار الحربي (2002) إلى أن اهتمام الباحثين من علماء النفس والاجتماع والتربية في فترة

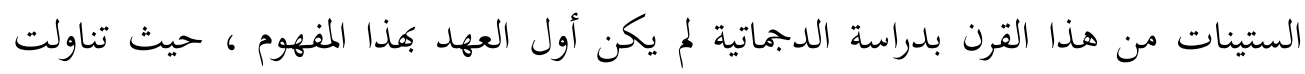

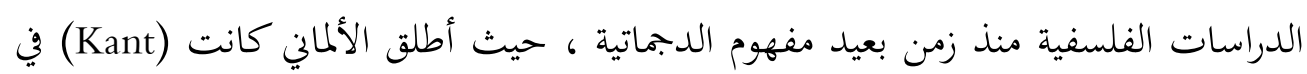

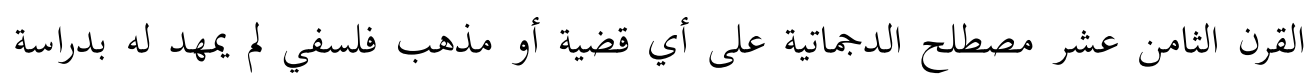
المقدمات.

\section{مفهوم الدوجماطيقية :}

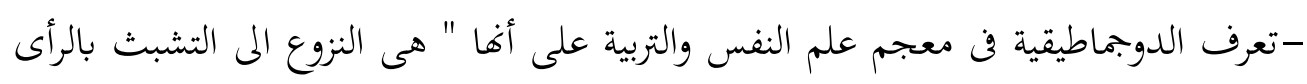

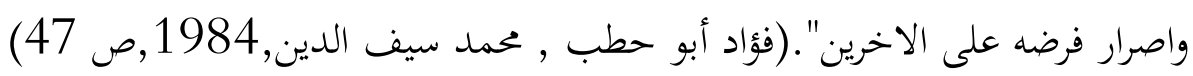

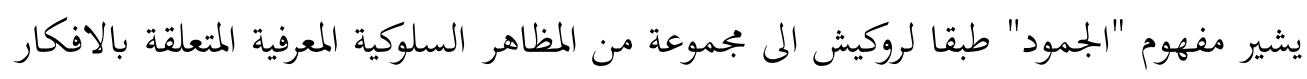

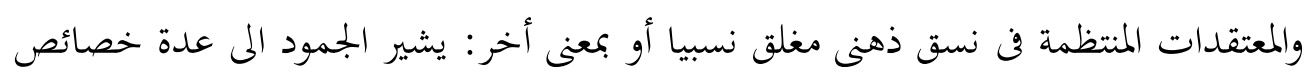
هى: طريقة منغلقة على التفكير تر تبط بأى أيدلوجية بصرف النظر عن مضموفا, ونظره

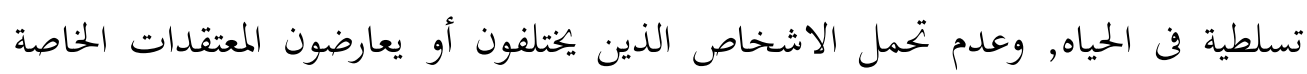
بأصحابها, وتسامح مع الاشخاص الذين يعتقدون معتقدات متشاهمة . 
أى أن روكيش يرادف بين مفهومى الجمود وانغلاق الذهن, والشخص الجامد ذهنيا (اى منغلق الذهن) يتميز بدرجة مرتفعة من الاستعداد لرفض المعارضة والخفاض نسبى للترابط بين أنساق الاعتقاد وتعدد المعارف الاكثر أعتمادا على رغبات غير ملائمة أو على سلطة مرنس

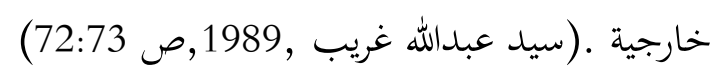
- يعرف معجم علم النفس والطب النفسى الدوجماتية dogmatism على النها التشبث بالافكار والمعتقدات الخاصة بالفرد , وعدم الاستعداد لمناقشة الافكار الاخرى لقناعته بخطئها وانحرافها. بالار و - يعرف أيضا dogmatic على اها الفكرة القاطعة أو الجازمة التى لاتحتمل النقاش , كما

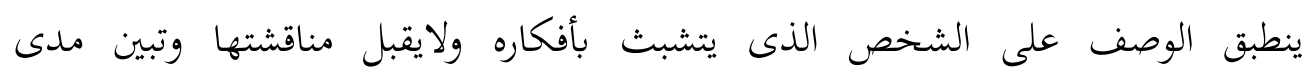

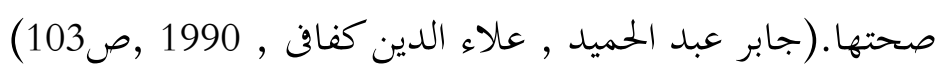
- جاء فن المعجم الفلسفى أن الدوجماتية هى " ابتحاه يذهب المى اثبات قيمة العقل وقدرته

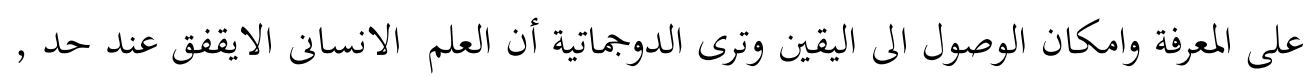
وتؤكد قدرة العقل على المعرفة والتوصل الم اليقين , قد ساءت هذه النزعة في فلسفة العقليين

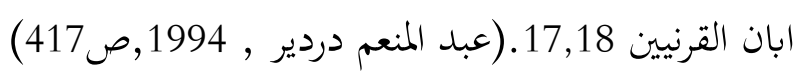
ولكن هذا المعنى لم يلبث ان تغير على يد الفيلسوف الالمانى كانت ) الذى هاجم الدوبماتية

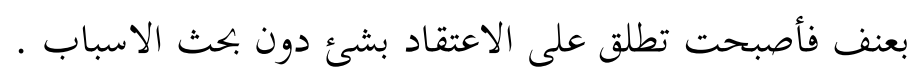

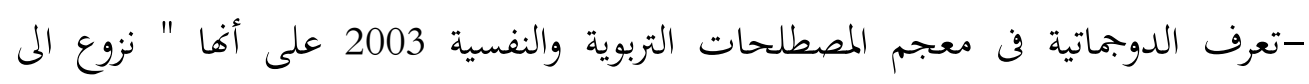

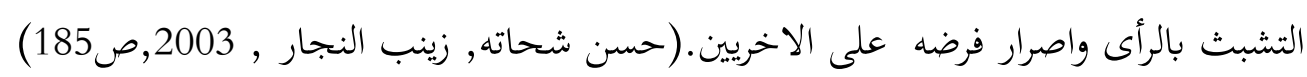

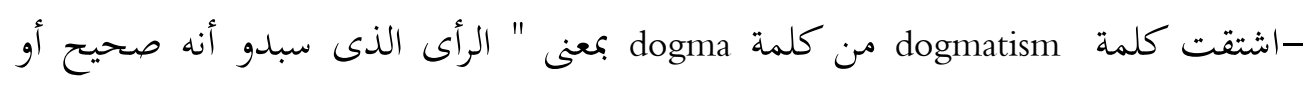

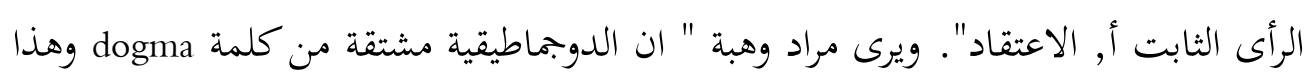

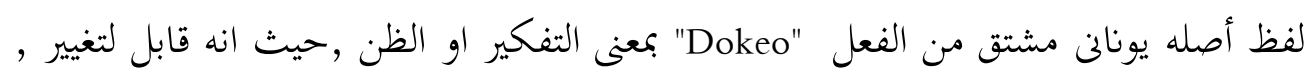

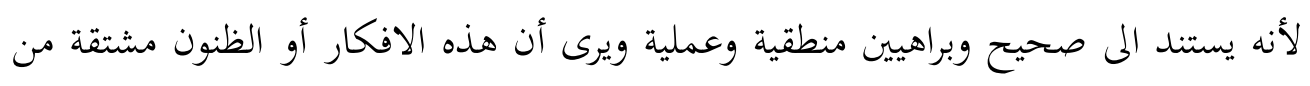

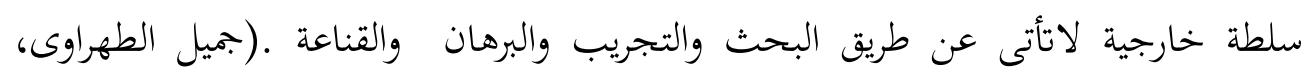

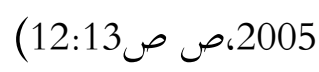


ويعرف قاموس وبستر Webster الدوجماطيقية بأها نظام التفكير التأملى القائم على ميادئ

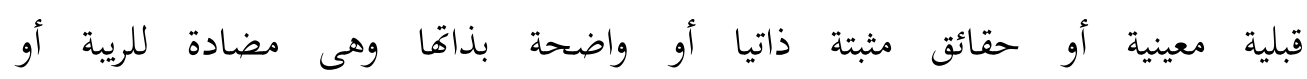
الشك(skepticism). ويرى روكيتش Rokeach.1960 أن الدوجماطيقية اسلوب للعقل يتسم بالتفكير الجامد وتمتد فن الشخصية على متصل بين قطبين أحدهما هو الانغلاق والاخر هو الانفتاح ويتسم أصحابها بالتشدد مع معارضيهم , دون ايه محاولة للتعرف على افكارهم ومعتقداتم المناهضة والتفكير هوني

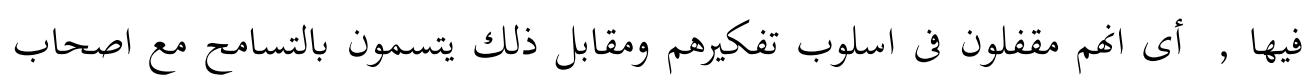

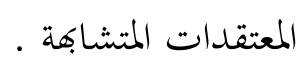

ويرى البعض ان الدوجماطيقى يتشبث بنمط سلوكى معين لا يصلح للموقف الذى يستخدم

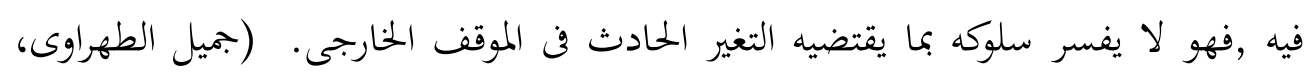
$(14,2005$

وفى السبعينات من القرن العشرين أكد ويلسون ان (الدوجماطيقية ) تكمن وراء الاتحاهات

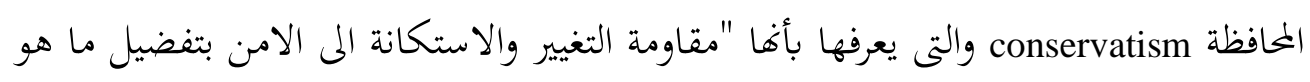
موروث وتقليدى في المواقف والسلوك وقد صمم مقياسا , تتمثل ابعاده في :

$$
\begin{aligned}
& \text { 1- الاصول الدينية } \\
& \text { 2- التوجه السياسى اليمينى النزعه } \\
& \text { 3- الاصرار على العقوبات والقواعد الصارمة } \\
& \text { 4- اللاتسامح ازاء الاقليات }
\end{aligned}
$$

5- تفضيل ما هو تقليدى فن الفن والملبس والمواقف. 6- النظرة التشاؤمية للمستقبل 7- النزعة الخرافية لتفسير العلم

$$
\begin{aligned}
& \text { 8- النزعة العسكرية (militarism). (جميل حسن الطهراوى ,2005,صنئ (14) }
\end{aligned}
$$

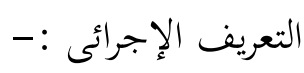


تعرف الباحثة الدوجماطيقية بأها " طريقة تفكير تزعم إمتلاك الحقيقة المطلقة بشكل شامل واليقين المطلق دون الإستناد إلى براهين يقينية وإنكار الآخر طالما أنه خالف أفكاره ومعتقداته ، ويتسم بالجمود والتصلب الفكرى وهو مبدأ التعصب ، والتزمت ، والحروب العقائدية ".

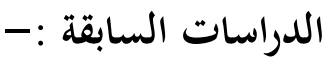 \\ دراسات تناولت مفهوم الدوجماطيقية: -}

هدفت دراسة مارلي (1988)إلى معرفة علاقة مفهوم الذات والدوجماتية ووجهة الضبط لدى طلبة كلية التربية والفرق بين الذكور والإناث في الدوجمانية حيث اشتملت العينة على (125) طالبًا في السنة النهائية، وتم استخدام مقياس روكيش للدوجمانية. وأظهرت النتائج فروقًا في الدوجمانية عائدة للنوع حيث كان الذكور أعلى دوجمانية من النساء. وفى دراسة ويلز Wells, M (1988) بعنوان: "الاتحاهات المتميزة المسبقة والسلوك، فعالية برنامج تعليمي وتدريبي تجريبي والدوجمانية. هدفت هذه الدراسة إلى تقييم مدى فاعلية برنامج تعلمي، برنامج تدريبي على الدوجماتية والاتجاهات المسبقة والسلوك. وتكونت عينة الدراسة من (279) طالبًا مبتدءًا من طلبة كلية التربية بجامعة (تكساس) التكنولوجية، وتم تقسيمهم إلى مجموعتين حسب مقياس (روكتيشن) للدوجماتية وهى الأكثر دوجماتية والأقل دوجماتية. واستخدم الباحث مقياس روكتيتش للدوجماتية الصورة (E) ومقياسين للتسامح والاتحاهات. وتبين من نتائج الدراسة أن المجموعة الأقل دوجماتية تأثرت بالبرنامج أكثر من المجموعة الأكثر دوجمانية وأن النتيجة العامة للدراسة هى خفض درجة الدوجماتية في كل المجموعتين ـ الأكثر والأقل دوجماتية ـ ولكن بنسبة أكبر لدى المجموعة الأقل دوجماتية. وهدفت دراسة إبراهيم إبراهيم، عبد الرحمن سليمان (1992) الدراسة إلى التعرف على العلاقة بين الدوجمانية واتخاذ القرار من خلال الدراسة الأمبيريقة لعينة من طلاب وطالبات جامعة 
قطر. واستخدم الباحثان مقياس الدوجماتية أعداد الباحثان، اختبار القدرة على اتخاذ القرار لطلبة المرحلة الثانوية والجامعات ومواقف من الحياة. كانت عينة الدراسة مكونة من (480) طالب وطالبة من طلال جامعة قطر . وكانت من أهم النتائج: وجود فروق ذات دلالة إحصائية بين الطلاب مرتفعي الدوجماتية ومنخفضي الدوجماتية في اختبار القدرة على اتخاذ القرار لصالح مجموعة الطلاب منخفضوا الدوجماتية. وجود فروق بين الطالبات مرتفعات الدوجماتية ومنخفضات الدوجماتية في اختبار القدرة على اتخاذ القرار. عدم وجود فروق ذات دلالة إحصائية بين متوسط مجموعة الطلاب منخفضوا الدوجماتية ومتوسط الطالبات منخفضات الدوجماتية في اختبار القدرة على اتخاذ القرار. عدم وجود فروق ذات دلالة إحصائية بين متوسط مجموعة الطلاب مرتفعي الدوجماتية والطالبات مرتفعات الدوجماتية في القدرة على اتخاذ القرار. هدفت دراسة الخميسي (1993) إلى الكشف عن بعض أوجه العلاقات بين ظاهرة التعصب الفكري أو العقائدي، والتطرف والعنف لدى الشباب المصري المتعلم بشكل خاص، والشباب العربي بوجه عام، وبين التعليم وإمكاناته وفعالياته الواقعية، والجهود التربوية، والخطاب التربوي المعاصر، كمضمون وآليات وتوجهات. اتبع الباحث في دراسة النظرية منهج التحليل النفسي، للإجابة عن تساؤل الدراسة الرئيس، حيث زواج بين التحليل وإعادة التركيب، واستجلاء المفاهيم، وتفسير الآراء، ومناقشة الإجراءات والعمليات ومعالجة المادة المتوفرة برؤية خاصة، وإطار معري لتفسير التعصب والتطرف تربويًا. وأظهرت نتائج الدراسة ما يلي: * أنه برغم تعدد أسباب شيوع التطرف، إلا أنه في التحليل النهائي، يعبر عن مشكلة تربوية في نشوئها وتناميها، لأن التطرف يتعلق أساسًا بغياب الحرية أو تقلصها في مختلف 
مناحي الحياة، وأن الحرية قضية "تربية قيمية". * أن مسببات وعوامل ظهور مشكلة التطرف الفكري ليست جميعها عوامل داخلية محلية، حيث لعبت وتلعب المتغيرات الإقليمية والعالمية دورًا فاعلاً في ظهورها وتناميها وتعقيد تفاعلاتحا. * أن الوضع الراهن للواقع الثقافي والفكري العربي العام لا يخلو من أزمات تسهم إلى حد كبير في إنتاج التعصب والجمود الفكري، والتطرف العقدي على حساب التسامح الفكري والثقافي. وف دراسة حسين طاحون وعبد الرممن عثمان (1996): عن العلاقة بين الاتحاهات العصبية والدوجماطيقية وبعض الأساليب المعرفية. وكانت عينة الدراسة (267) من الطلبة الجامعيين بجامعة الزقازيق واستخدم الباحثان اختبار (الابتاهات الدفعية من إعداد الباحثين) واختبار الأشكال المتضمنة والصورة الجمعية، لقياس الاعتماد/الاستقلال من الجمال واختبار الأشكال المألوفة لقياس التروي/ الاندفاع ومقياس الدوجماطيقية لدوكيتش، وأظهرت نتائج الدراسة أن هناك علاقة ارتباط بين الدوجماطيقية والاتحاهات التعصبية القومية والرياضية ونحو الجنس الأخر ووجدت فروق دالة لصالح الإناث في الابتاهات التعصبية الدينية. وكانت دراسة محمود غلاب ومحمد الدسوقي (1994):بعنوان "دراسة نفسية مقارنة بين المتدينين جوهريًا والمتدينين ظاهريًا في الاتحاه نخو العنف وبعض خصائص الشخصية". وهدفت إلى التعرف على العلاقة بين التوجه الديني بشقيه الجوهري والظاهري في الابحاه نخو العنف وخصائص الشخصية، ونملت الدراسة عينة من طلاب الجامعات المصرية ن = (454) طالبًا وطالبة منهم (236) ذكرًا و (218) أنثى، وبلغ المسلمين منهم (273) طالبًا وطالبة، وعدد المسيحيين (181) طالبًا وطالبة، تتراوح أعمارهم بين (18 و 22) عامًا واستخدمت (8) مقاييس هى التوجه الديني إعداد عبد الرقيب البحيري، مقياس الاتحاه نحو 
العنف، قائمة أيزنك للشخصية، ومقياس الجمود ومقياس السيطرة، واختبار تأكيد الذات، ومقياس روثر لوجهة الضبط، واختبار سمة القلق للكبار. وأشارت نتائج اختبار (ت) إلى وجود فروق بين مرتفعي التوجه الديني الظاهري والجوهري في الاتحاه نحو العنف وذلك في ابتحاه المجموعة الأولى بالنسبة لكل من المسلمين والمسيحيين، ووجدت فروق ذات دلالة بين مرتفعي التوجه الديني الظاهري في العصابية والجمود والقلق في ابتحاه مرتفعي التوجه الديني الظاهري، وكانت الفروق في ابتاه مرتفعي التوجه الديني الجوهري في تأكيد الذات وذلك في عينة المسلمين وكذلك المسيحيين، ووجد ارتباط إيجابي دال بين لتوجه الديني الظاهري نهو العنف، وكلاً من العصابية وتأكيد الذات والسيطرة والقلق لدى المسلمين وكذلك بين التوجه الديني والجوهري وبين السيطرة ووجهة الضبط، ووجد ارتباط موجب دال بين التوجه الديني الظاهري من الانبساطيين والعصابية والجمود والقلق لدى عينة المسيحيين.

\section{دراسات تناولت مفهوم أحادية العقلية :}

سعت دراسة عثمان حمود خضر (2006) هذه الدراسة إلى معرفة طبيعة العلاقة المختملة بين التدين والشخصية أحادية العقلية، وفيما إذا كانت هناك فروق بين الجنسية وبين عينة الأئمة والخطباء والطلبة الذكور في مقاييس التدين والشخصية أحادية العقلية واستخدمت لهذا الغرض 244 مفحوصًا (الذكور ن = 165، والإناث ن = 68) منهم 55 إمام وخطيبًا يعملون في وزارة الأوقاف الكويتية والباقي ن = 189 طلاب من جامعة الكويت، وخلصت الدراسة إلى أن هناك ارتباطًا عكسيًا ودال إحصائيًا بين الدرجة الكلية على مقاييس السلوك الديني (العبادات، والعادات، والمنجيات والدرجة الكلية والدرجة الكلية على مقياس أحادية العقلية ولم يظهر ارتباط جوهري في مقياسي الإيمانيات والمهلكات، كما أظهرت النتائج أن مجموعة 
الخطباء حصلوا على متوسطات أعلى جوهريًا من متوسطات الطلاب في كل من مقاييس

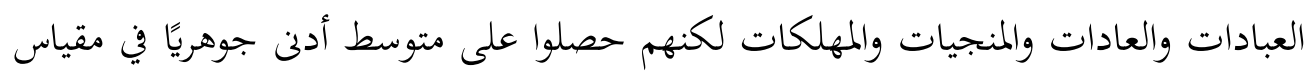
أحادية العقلية كما أفرزةًا النتائج أن الإناث حصلن على متوسطات أعلى وبصورة جوهرية من الذكور في كل العبادات والمنحنيات والمهلكات والدرجة الكلية في المقياس الديني، ولكنهن حصلن على متوسط أدن وبصورة جوهرية في مقياس أحادية العقلية وفي جميع المقارنات بين الجمموعات المختلفة لم تظهر فروق جوهرية بينها في قياس الإيمانيات. هدفت دراسة تركي بندر سوعان العنزي (2008) إلى المقارنة عبر الحضارات الثقافية بين الكويتيين والمصريين في الاتجاه نخو العنف السياسي وإلى أي مدى يرتبط الاتحاه الابتحاه نو العنف السياسي بأبعاده المختلفة (المكون المعريف ـ المكون الوجداني ـ المكون النزوعي) بالأحادية العقلية. استخدم الباحث المنهج الوصفي المقارن والذي يعد دائمًا للدراسات عبر الثقافات المختلفة للكشف عن الفروق بين متغيرات البحث لدى المصريين والكويتيين وكانت من أهم النتائج: 1.وجود فروق دالة إحصائيًا بين المصريين والكويتيين من عينة الدراسة في الأحادية العقلية عند مستوى (0.001). 2.لا توجد فروق دالة بين الذكور والإناث من أفراد العينة الكلية في الأحادية العقلية. دراسة عثمان الخضر (2004) بعنوان "الغضب وعلاقته بمتغيرات الصحة النفسية". هدفت الدراسة تحديد علاقة الغضب والتعبير عنه بكل من ضبط النفس، وسمة القلق، والصحة العامة وأحادية العقلية، والتفاؤل والتشاؤم، ووجهة الضبط واحترام الذات، الحساسية من الفشل واجترار خبرات الماضي المؤمة، وتكونت العينة من (145) طالبًا وطالبة من طلاب جامعة الكويت، واستخدم الباحث في دراسته قائمة بحالة الغضب وسمته والتعبير عنه لسبيليرجر 
ولندن، ترجمة عبد الفتاح القرشي (1997)، واستخبار الصحة العامة لهدى جعفر (1999)، والقائمة العربية للتفاؤل والتشاؤم لأحمد عبد الخالق (1996) وقائمة سمة القلق لعبد الخالق (1992) ومقياس أحادية العقلية من تصميم صفوت فرج (2001)، ومقياس ضبط النفس لهارسون جوخ تعريب مصطفى تركي (1989)، ومقياس الحساسية من الفشل واجترار أحداث الماضي المؤلمة إعداد الباحث ومقياس وجهة الضبط لعبد الخالق (1999) ومقياس احترام الذات لممدوح سلامة (1991)، وتوصلت هذه الدراسة إلى وجود علاقة إيجابية دالة إحصائيًا بين كل من حالة الغضب وسمته وقمعه.

\section{دراسة تناولت متغير أحادية العقلية مع الدوجماطيقية:-}

هدفت دراسة عبد الحميد عبد العظيم رجيعة (2007) إلى استكشاف العلاقة بين: التصلب والتسلطية، والدوجماتية، والمحافظة، التعصب، أحادية العقلية، أحادية الرؤية، وتحمل الغموض، ونوعية هذه العلاقة. إن وجدت. كما همدف إلى كسف النقاب عن تمايز هذه المتغيرات لدى طالبات الجامعة، والتعرف على مدى الاختلاف والتباين، أو التحقق من تماثلها وتشابهها واقتراح ضمها توحيدًا للغلة العلم والتحاور. أدوات الدراسة:. مقياس التصلب إعداد جف وترجمة محمد سلامة (1983).2مقياس كاليفورنيا للتسلطية إعداد أدورنو وزملاءه ترجمة محمد سلامة (1983).3مقياس الدوجماتية إعداد روكيتش ترجمة محمد سلامة (1983).4-مقياس التعصب إعداد معتز سيد عبد الله (2000).5مقياس نورتون لتحمل الغموض ترجمة صلاح أبو ناهية، رشاد موسى (1987).ممقياس أحادية العقلية إعداد رشدي فام، قدري حفني (1994).7مقياس المحافظة 
إعداد كوهن، ترجمة محمد سلامة (1983). 8مقياس أحادية الرؤية إعداد صفوت فرج

وتم التحقق من صدق وثبات هذه المقاييس بتطبيقها على عينة بلغت 58 طالبًا بالفرقة الرابعة (لغة عربية) بكلية التربية بالسويس، وتكونت عينة الدراسة من 316 طالبة بالفرقة الرابعة جميع الشعب الأدبية (عام ـ ابتدائي) بكلية التربية بالسويس.

ولتحليل الإحصائي للبيانات تم استخدام معامل الارتباط الخطي ليبرسون، التحليل العاملي بطريقة المكونات الأساسية ليهوتلينج مع التنوير المتعامد بطريقة فاريماكس. وتوصلت الدراسة إلى النتائج التالية: 1. وجود ارتباط موجب ودال إحصائيًا (عند مستوى 0.05) بين الدوجماتية وكل من التسلطية، التعصب، المحافظة، تحمل الغموض، أحادية الرؤية.

2 وجود ارتباط موجب ودال إحصائيًا (عند مستوى 0.01) بين الدوجماتية وأحادية العقلية. 3ـ وجود ارتباط موجب ودال إحصائيًا (عند مستوى 0.01) بين التسلطية وكل من التصلب، أحادية العقلية، تحمل الغموض.

4ـ وجود ارتباط موجب ودال إحصائيًا (عند مستوى 0.05) بين كل من المحافظة وتحمل

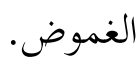

5ـ وجود ارتباط موجب ودال إحصائيًا (عند مستوى 0.05) بين التعصب والمحافظة، وجود ارتباط موجب ودال إحصائيًا (عند مستوى 0.01) بين التعصب وأحادية العقلية. 6ـ وجود ارتباط موجب ودال إحصائيًا (عند مستوى 0.01) بين المحافظة وتحمل الغموض. 
7. وجود ارتباط موجب ودال إحصائيًا (عند مستوى 0.01) بين أحادية العقلية وتحمل الغموض، وارتباط موجب دال عند مستوى 0.05 بين أحادية العقلية وأحادية الرؤية.

منهج الدراسة أولا. الفرض :- توجد علاقة دالة إحصائياً بين متغير أحادية العقلية ومتغير الدوجماطيقية ثانيا. العينة

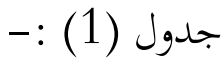

\begin{tabular}{|c|c|c|c|}
\hline النسبه المئوية & العدد & المتغير & \\
\hline$\% 39,3$ & 129 & -ذكر & النوع \\
\hline$\% 60,7$ & 199 & - & \\
\hline & & \multirow{3}{*}{ - - - } & \multirow{3}{*}{ المعليمى } \\
\hline$\% 47,9$ & 157 & & \\
\hline$\% 52,1$ & 171 & & \\
\hline
\end{tabular}

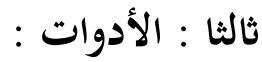
1- إختبار قياس أحادية العقلية إعداد ا.د صفوت فرج (2001) ويتكون من 66 بندا.وهو محاولة للكشف عن عدد من الجوانب الإيجابية والسلبية فن النمط المعرف لأحادى العقلية وبينما كانت بنود المقياس محايدة إلا إها كانت قادرة على الكشف عن نغط يشغل متصلا

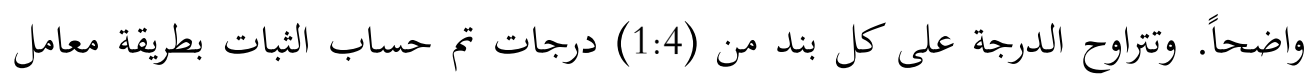
ألفاكرونباخ وكانت (844,) وتم حساب الصدق الداخلى للمقياس وكانت . العاملى

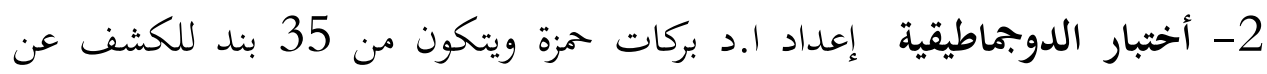

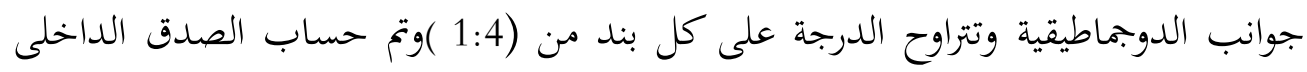

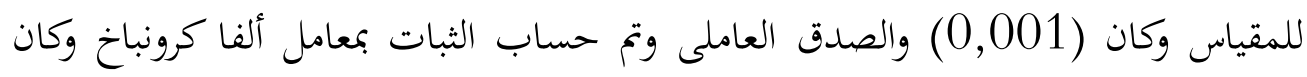


الفرض :- توجد علاقة دالة إحصائياً بين متغير أحادية العقلية ومتغير الدوجماطيقية .

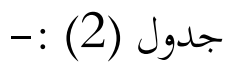

\begin{tabular}{|r|r|r|}
\hline أحادية العقلية & \\
\hline الدوجماطية العقلية & \\
\hline 1 & 1 & \\
\hline & & \\
\hline
\end{tabular}

- أسفرت النتائج عن وجود علاقة أرتباطية موجبة دالة عند 0,001 بين الدوبماطيقية وأحادية العقلية. أى أن الدوجماطيقية ترتبط بأحادية العقلية إرتباط دال موجب أى كلما زادت الدوجماطيقية

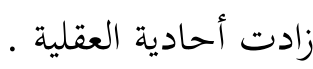
وتتفق هذه النتيجه مع دراسة عبد الحميد عبد العظيم رجيعة (2007) هدفت الدراسة إلى استكشاف العلاقة بين: التصلب والتسلطية، والدوجماتية، والمحافظة، التعصب، أحادية

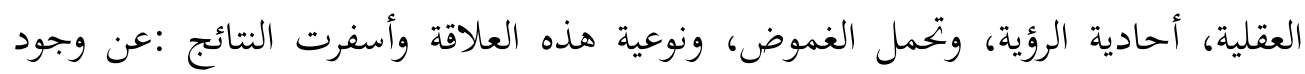

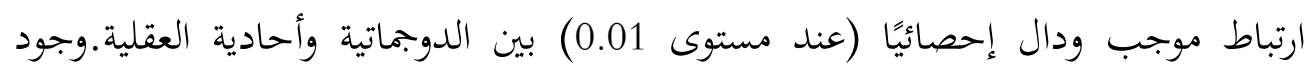

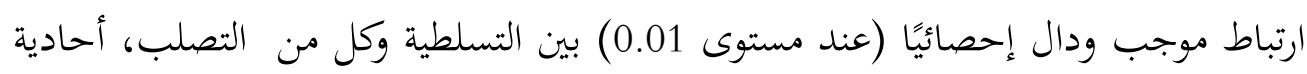
العقلية، تحمل الغموض. وجود ارتباط موجب ودال إحصائيًا (عند مستوى 0.05) بين

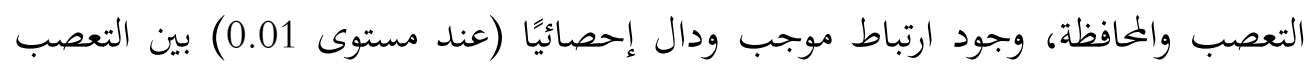
وأحادية العقلية.وجود ارتباط موجب ودال إحصائيًا (عند مستوى 0.01) بين أحادية العقلية وتحمل الغموض، وارتباط موجب دال عند مستوى 0.05 بين أحادية العقلية وأحادية الرؤية. 
ومن خلال الاطار النظرى لمفاهيم البحث يقول صفوت فرج يتحدد السواء دائماً من خلال

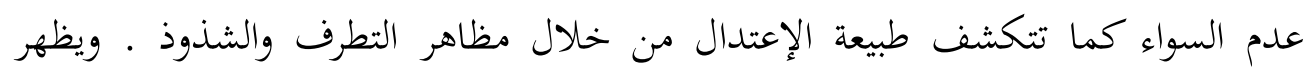
الفحص الدقيق أن هناك خصائص غير سوية شاذه تناقض طبيعة العصر وتوجهاته الإنسانية والتطورية وتقف حائلاً بين الفرد ومواكبة حركة التطور الإجتماعى والتقدم الحضارى. وبتتمع هذه الخصائص الغير سوية والشاذه وتتلخص فيما يمكن أن نطلق عليه " أحادية العقلية " single mindedness ويقصد بأحادية العقلية مجموعة من الخصائص المعرفية والمزاجية التى تشكل سلوكاً متسقاً يتعارض مع قبول التنوع ويرفض الحركة بين البدائل ويدور فن إطار تقريرى convergent ، ويتجنب الإحتكاك بالجديد أو المجهول ويحتمى باليقين

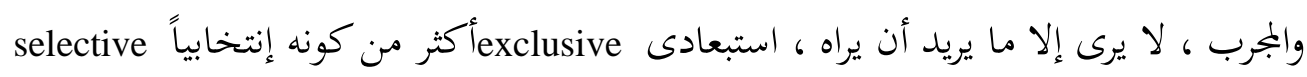
، يتحرك وفق مسارات صارمه ويتجاهل الإحتمالية ولا يستطيع أن يتحول إلى التفكير ينري التغييرى divergent الطابع ، ويعزل نفسه عن مجتمعه ويكرس نفسه لأهداف ضيقه ومحدده (صفوت فرج ، 2000 ، ص 15) .

يعد من الصعب فصل مفهوم أحادية العقلية عن بعض المفاهيم مثل التصلب (الجمود العقلى) Rigidity ، التحيز Bias ، التعصب prejudice ، النفور من الغموض ، القلق

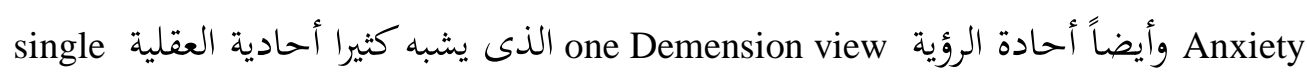
mindedness عام يضم ويختزل مفاهيم كثيرة بداخله . والدوجماطيقية أو الانغلاق المعرفي Dogmatism مفهوم واسع في حالات مختلفة يؤدي إلى معنى واحد أو المعنى نفسه وهو التفكير الجامد والانغلاق الذهني والجمود الذهني أو العقلي أو ولأ الفكري والقطعية والتوكيدية والمعتقدية والعموض ومواجهة كل ما هو مضاد أو جديد فهو يقع بين قطبي الصواب والخطأ أو أبيض وأسود. أن الشخص الجامد ذهنياً (أي منغلق الذهن) يتميز بدرجة مرتفعة من الإسئ واستعدداد لرفض

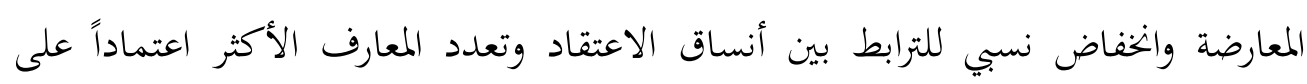


رغبات غير ملائمة أو على سلطة خارجية. ويذكر (روكيش) 1960 أن (أدورنو) وزملاؤه قد

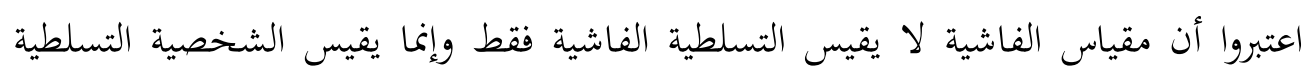

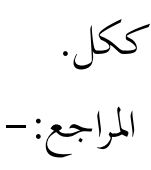

1- ابراهيم ابراهيم، عبدالرمن سليمان(1992): الدوجماتية وعلاقتها بإتخاذ القرار لدى عينه من طلبةجامعة عين شمس

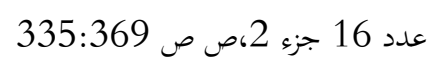

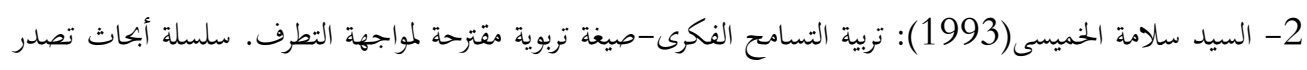

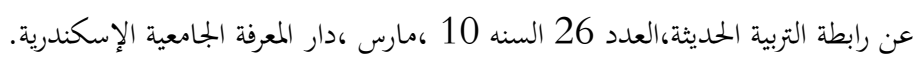

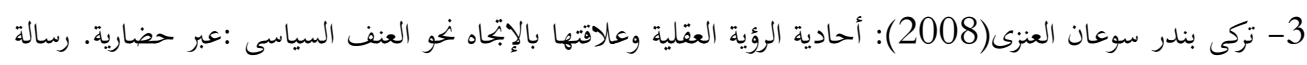

ماجستير ، كلية الآداب ، جامعة حلوان.

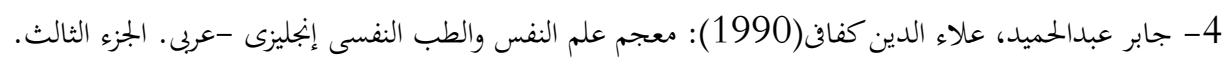

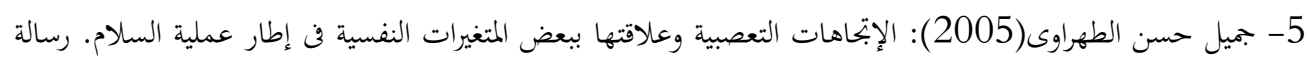

دكتوراة، كلية الآداب، جامعة عين شمس.

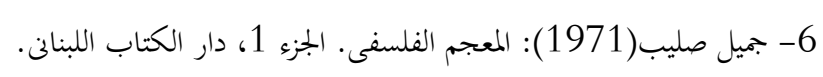

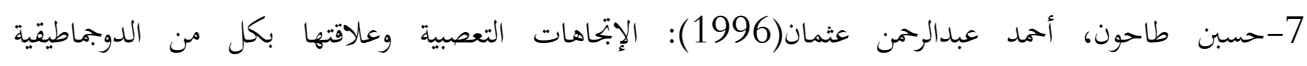

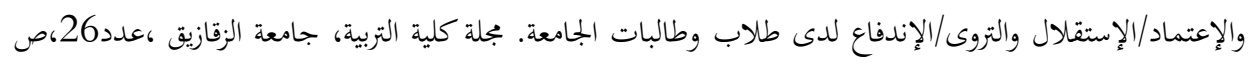

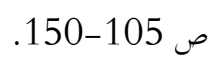

8-حسن شحاته، زينب النجار(150-1053): معجم المصطلحات التربويه والنفسية. الدار المصرية اللبنانة، الطبعة الأولى ، أكتوبر.

9-صفوت فرج (2000): الشخصية أحادية العقلية- خصائص النط ومتعلقاته. بجلد 21، رسالة 155، ديسمبر، بجلة

$$
\text { العلوم الإجتماعية. }
$$

10- عبدالحميد عبد العظيم رجيعة(2007): دراسه عاملية لبعض سمات الشخصية السلبية لدى طالبات الجامعة. العدد

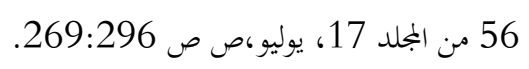

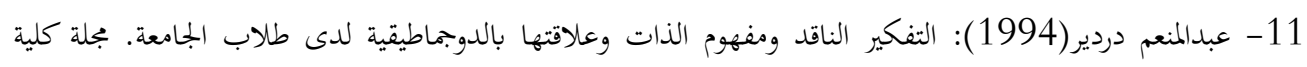

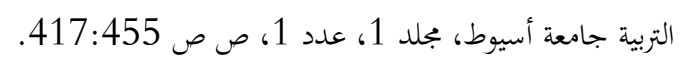

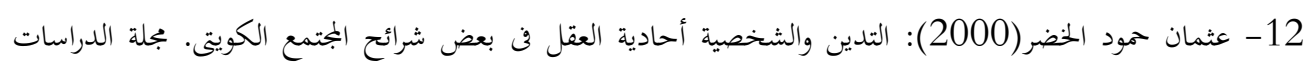

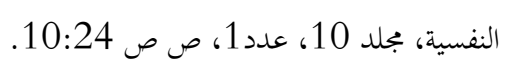

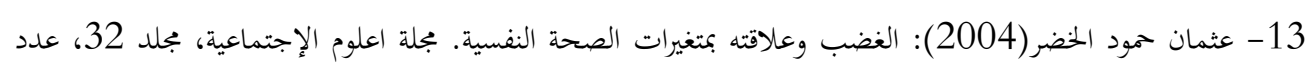

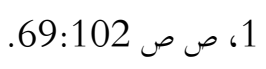


14- على صكر جابر(2008): محددات أداء مهام حل المشكلات لدى طلبة الجامعة من زوى الإنغلاق المعرفى(

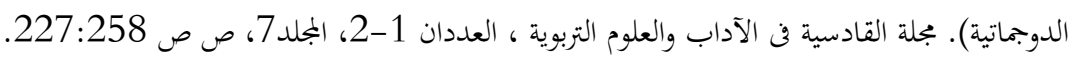

15- فؤاد أبو حطب، محد سيف الدين(1984): معجم علم النفس والتربية ، الهيئة العامة للمطابع الأميرية، الإدارة العامة

$$
\text { للمعجمات، الجزء الأول. }
$$

16- كمال الدسوقى(1988): ذخيرة علوم النفس. بجلد1 القاهرة، الدار الدولية للتوزيع.

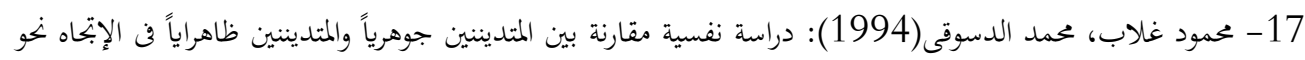

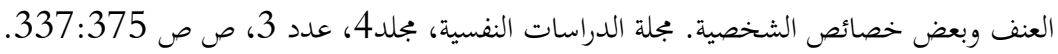

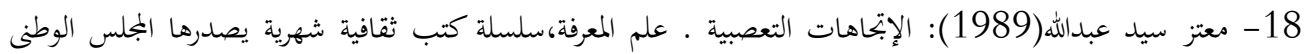

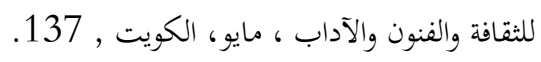

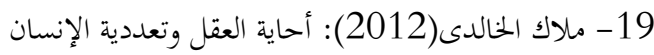

www.al-jazirah.com/culture/2012/27092012/fadaat9.htm.

20- ناصر دسوقى(1991): الدوجماتية وعلاقتها بمستوى الطموح لدى طلاب الجامعة من أبناء الريف والحضر. رسالة

$$
\text { ماجستير ، كلية تربية ، جامعة سوهاج. }
$$

21 ناصر عبدالله الحربى(2003): علاقة الجمود الفكرى (الدوجماتية) بأنماط التعلم والتفكير لدى طلابة جاب وطالبات المرحلة

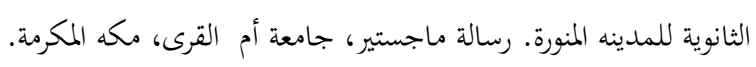

23- Rokeach,M(1960). the open and closed minded, new york, Basic Book, Inc. 24-Wells,Michal(1998)prejudicial attitudes and behaviors, the effects of didactic learning and dogmatism, vol 50-05 of dissertation abstracts internation. 